\title{
A Rare Case of Psychosis in Ushers's Syndrome in Absence of Hallucinations
}

\section{Halüsinasyon Yokluğunda Ushers Sendromunda Nadir Görülen Bir Psikoz Olgusu}

\author{
Haradanahalli Giriprakash Kshamaa ${ }^{1}$, Manju Aswath ${ }^{1}$, Lakshmi V Pandit ${ }^{1}$
}

${ }^{1}$ Kempegowda Institute of Medical Sciences, Department of Psychiatry, VV Puram, Bangalore, India

\section{Öz}

Usher sendromu işitme ve görme kaybına yol açan klinik ve genetik olarak heterojen bir sendromdur.Üç tip Ushers sendromu, işitme kaybının şiddetine ve vestibüler semptomların varlığına veya yokluğuna bağlı olarak tanımlanmıştır. Ushers sendromu ile ilişkili birkaç zihinsel bozukluk görülse de, tıp camiasında aynı farkındalığın eksikliği görülmektedir Ushers sendromu ve psikozu ile ilgili sadece birkaç olgu sunumu olmuştur ve bu olgularda görsel ve işitsel halüsinasyonlar baskın özelliktir.Bu nedenle yazar, herhangi bir halüsinasyon olmaması durumunda benzersiz bir ushers sendromu ve psikoz vakasını tartışır.

Address correspondence to: Haradanahalli Giriprakash Kshamaa, Kempegowda Institute of Medical Sciences, Department of Psychiatry, VV Puram, Bangalore, India e-mail: kshamaa.hg@gmail.com

\section{Abstract}

Usher syndrome is a clinically and genetically heterogeneous syndrome leading to hearing and vision loss. Three types of Ushers syndrome have been described based on severity of hearing loss and presence or absence of vestibular symptoms. Although several mental disorders have been seen to be associated with Ushers syndrome, the awareness of the same is lacking in the medical community. There have been only few case reports of Ushers syndrome and psychosis, with visual and auditory hallucinations being the predominant feature in these cases. Hereby the author discusses a unique case of ushers syndrome and psychosis in absence of any hallucinations.

Key words: Usher's syndrome, psychotic disorders, case reports, rare diseases

Gelis Tarihi/Received: 22 June 2021 Kabul Tarihi/Accepted: 31 August 2021

Cite this article as: Kshamaa HG, Aswath M, Pandit LV. A Rare Case of Psychosis in Ushers's Syndrome in Absence of Hallucinations. Selcuk Med J 2021;37(3): 276-278
Disclosure: None of the authors has a financial interest in any of the products, devices, or drugs mentioned in this article. The research was not sponsored by an outside organization. All authors have agreed to allow full access to the primary data and to allow the journal to review the data if requested. 


\section{INTRODUCTION}

Usher's syndrome is a heterogeneous autosomal recessive disorder, primarily associated with sensorineural hearing loss, retinitis pigmentosa and in some variants vestibular dysfunction. It is also known as Hallgren syndrome, Usher-Hallgren syndrome, Retinitis pigmentosa-dysacusis syndrome and Dystrophia retinae dysacusis syndrome. Usher's Dystrophia retinae dysacusis syndrome. Usher's tyse of 3.2 $6.2 / 100,000(1,2)$. Although no there is no literature on prevalence of Usher's syndrome in India, in a longitudinal study (3) $14.28 \%$ of patients with syndromic deafness were diagnosed with Usher's syndrome. Epidemiological studies report varying prevalence rates of mental disorders in these patients ranging from $15 \%$ to $60 \%$ (4). Herein, we report a case of a middle aged man with Usher's syndrome with psychosis.

Mr. S, 35 year old male patient presented to the psychiatric out-patient department (OPD) in a tertiary care center with episodes of altered behaviour since past 3 years, most recent episode since 12 days. $\mathrm{He}$ also had a history of decreased vision since past 10 years and hearing difficulty since 8 years. He 10 years and hearing difficulty since 8 years. He presented with an acute episode of suspiciousness 3 years back with strong beliefs of black magic being performed on him, and was extremely fearful as he felt his family members and co-workers were trying to harm. It was found that patient gradually stopped eating food at home thinking it was poisoned and his interaction with family members was also markedly reduced. He stopped going to the work and stayed aloof. His self care also deteriorated. 1 month following the onset of symptoms family members took him to a psychiatrist, where he was prescribed medications. According to the family he took the medications for a period of 2 months and stopped it on his own as he attained pre morbid levels of functioning.

Mr. S was brought to our OPD with 12 days history of similar symptoms in the past along with complaints that his actions and feelings are being controlled by someone else. On mental status examination patient was unkempt, perplexed, restume and tone of speech, delusions of persecution, made act and made affect with anxious mood. Judgment was impaired with absent insight. A psychiatric diagnosis of acute schizophrenia - like psychotic disorder was made according to Intenational Classification of Disorder - 10 (ICD-10). A differential diagnosis of paranoid schizophrenia was considered because of the past history.

Family history revealed that his maternal cousin brother suffered from Deafness and Hearing loss and expired at a young age. Moderate to severe sensori-neural deafness was found in both ears on Pure-Tone Audiometry. Ophthalmological check-up revealed bilateral retinitis pigmentosa with tunne vision. Other brod investigations were within tunnel re within normal

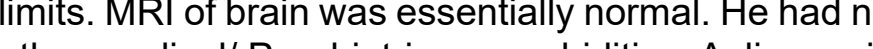
ther medical/ Psychiatric co-morbidities. A diagnosi Dave based on Davenport and Omenn criteria (5). Mr. S was started on olanzepine $5 \mathrm{mg}$, gradually increased to $10 \mathrm{mg}$ in 3 weeks. He started showing improvement within a few days of initiating treatment with minimal side effects. He reached pre-morbid levels in 2 months in is currently on regular follow-ups.

\section{DISCUSSION}

The data regarding Ushers syndrome and desychosis is conflicting, with some studies showing prevalence $4.5 \%$ (6) while others as high as $23 \%$ (7). Most common form psychosis diagnosed in these individuals was of schizophreniform spectrum. It was found that visual and auditory hallucinations the was foution the discussed prophrenia-like psychosis. However, the highlight of this particular case is the absence of auditory hallucinations with presence of made phenomenon. There has been $\mathrm{no}$ concrete evidence for the causation of psychosis in Ushers syndrome. However various theories have been put forward. A common gene hypothesis for the causation of both ushers and psychosis has bee put forward. Schizophrenia is a polygenic disorder. Genetic loci 11q in type I and 5q in type II associated with Usher's syndrome are also implicated in schizophrenia. In addition DISC1 on chromosome 1q42.2 which is a possible causative gene in schizophrenia is on the same chromosome and close to the USH2A gene (8-11). Neuro-anatomica similarities like smaller brain volume and focal and diffuse atrophic changes in the supratentorial brain has been noted in both the conditions $(0,12)$. Studies has ben no $(9,12)$. Studies have show that there is deficient development of the theory of mind abilities in prelingually deaf patients (13). An).

other theory of relevance is stress-related theory. The chronic stress due to auditory and visual impairment leads to increased vulnerability in the patient for psychiatric disorders such as depression and psychosis (9). The current study highlights the presence of psychiatric illness in individuals with Ushers syndrome. This throws light on the importance of educating the opthalmologists and oto-laryngorhinologists regarding recognition of mental illnesses in these individuals and timely referrals, thereby these individuals and timely referrals, thereby providing them with holistic treatment.

Consent: Written informed consent was obtained from the patient for publication of this case report.

Conflict of interest: Authors declare that there is no conflict of interest between the authors of the article.

Financial conflict of interest: Authors declare that they did not receive any financial support in this study.

Address correspondence to: Haradanahalli Giriprakash Kshamaa, Kempegowda Institute of Medical Sciences, e-mail: kshamaa.hg@gmail.com

\section{REFERENCES}

1. Rosenberg T, Haim M, Hauch AM, et al. The prevalence of usher syndrome and other retinal dystrophy-hearin

Boughman JA, Vernon M, Shaver KA, Usher syndrome: Definition and estimate of prevalence from two high-risk populations. J Chronic Dis 1983;36(8):595-603.

3. Arumugam SV, Paramasivan VK, Murali S, et al. Syndromic deafness-prevalence, distribution and hearing management

4rilly Bally D, Dechoulydelenclave MB, Lawwerer L. Hearing adolescents. Review of the recent literature. L'Encéphale 2003;29:329-37.

5. Mets MB, Young NM, Pass A, et al. Early diagnosis of Usher syndrome in children. Trans Am Ophthalmol Soc. 2000;98:237-42; discussion 243-245

Nuutila A. Dystrophia retinae pigmentosa-dysacusis syndrome (DRD): A study of the

7. Hallgren B. Retinitis pigmentosa combined with congenital deafness; With vestibulo-cerebellar ataxia and mental abnormality in a proportion of cases: A clinical and geneticostatistical study. Acta Psychiatr Scand Suppl 1959;34:1-101.

Karjalainen S, Terásvirta M, Karija J, et al. An unusual otological manifestation o

McDonald C, Kenna P, Larkin T. Retinitis pigmentosa and schizophrenia. Eur Psychiatry 1998:13:423-6.

0. Sharp CW, Muir WJ, Blackwood DH, et al. Schizophrenia and mental retardation associated in a pedigree with retinitis pigmentosa and sensonneral din

11. Wu CY, ChiuCC Usher syndrome with psychotic symptoms:
Two cases in
2006;60:626-8. Vhaefer GB, Bodensteiner JB, Thompson JN Jr., et al. global involvement. Am J Med Genet 1998;79:1-4.

13. Landsberger SA, Diaz DR. Identifying and assessing psychosis in deaf psychiatric patients. Curr Psychiatry Rep 2011;13:198-202 